\title{
Compositional Analysis of Beneficiated Fly Ashes
}

Paul E. Stutzman

Lilia Centeno

May, 1995

Building and Fire Research Laboratory

National Institute of Standards and Technology

Gaithersburg, MD 20899

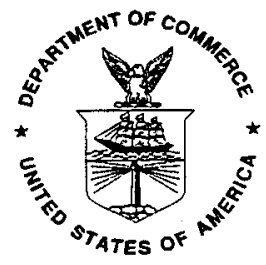

\section{U.S. DEPARTMENT OF COMMERCE}

Ronald H. Brown, Secretary

Technology Administration

Mary L. Good, Under Secretary for Technology

National Institute of Standards and Technology

Arati Prabhakar, Director 


\begin{abstract}
Understanding the material properties of mineral admixtures will help in providing a better understanding of the factors that control their performance in concrete. This study, a part of an effort by that includes reaction kinetics, microstructure development, and simulation modelling, examines the composition of the crystalline components of beneficiated fly ashes of different origin. Different sized fractions of fly ashes produced by burning coal in different boilers were examined by scanning electron microscopy and $\mathrm{X}$-ray powder diffraction. Each fly ash fraction was predominantly glassy material with minor amounts of quartz, mullite, anhydrite, magnetite, hematite, calcium oxide, and possibly periclase. The glassy fraction increased slightly with ash fineness and, for each size fraction, was typical of silicious glasses found in other fly ashes. Images of microstructures of mortars incorporating $25 \%$, by mass, fly ash replacement for cement show increased packing density with the finer ash fractions. The presence of unreacted fly ash and calcium hydroxide in the mortars after 60 days of wet curing indicates that the pozzolanic reaction is not complete. The similarity of ash phase compositions suggests that, at this age, strength gain may be influenced more by the particle size than by compositional differences among the ash fractions and ashes produced under different firing temperatures.
\end{abstract}

KEYWORDS: building technology; composition; concrete; fly ash; mineralogy; mortar; particle size 
Abstract............................

List of Tables.......................... $v$

List of Figures......................... v

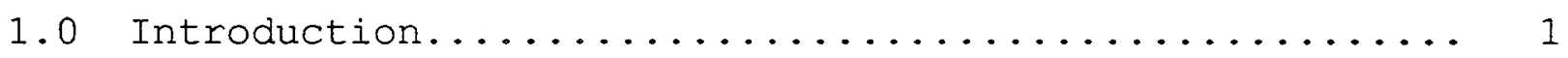

2.0 Pozzolanic Reactions........................ 2

3.0 Experimental Procedures..................... 3

3.I X-Ray Powder Diffraction (XRD) Analysis......... 4

3.2 Mortars with Fly Ash as a

Partial Cement Replacement................ 5

4.0 Results and Discussion.................... 5

4.1 Chemical Analysis.................... 5



4.3 Morphological Characteristics of Fly Ash........ 10

4.4 Mortars Containing Fly Ash............... 13

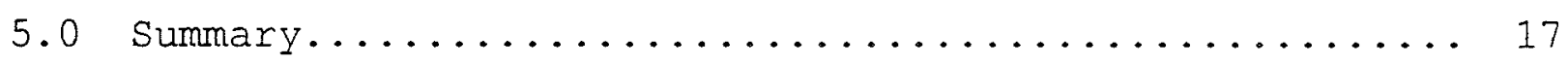

6.0 Acknowledgements....................... 17

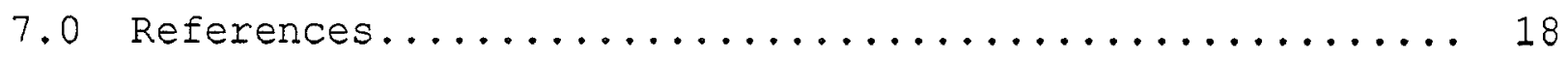


Table 1. Chemical Requirements for Fly Ash Classification According to ASTM C $618[13] \ldots \ldots \ldots \ldots \ldots \ldots \ldots . \ldots$

Table 2. Chemical Compositions, Loss-On-Ignition, Fineness for Size-Fractionated Fly Ash Subsamples as determined by Jaturapitakkul [6] ............6 6

Table 3. XRD phase fraction estimates for wet and dry-bottom boiler fly ash expressed as mass percent ....... 7

List of Figures

Figure 1. Dry-bottom ash diffraction patterns nested from finest to coarsest size fractions (bottom up) as samples H3F, H5F, H6F, H10F, H11F, H1C, and H>40. Phases include quartz (Q), mullite (M), hematite (H), magnetite (Ma), anhydrite $(\mathrm{A})$, periclase $(\mathrm{P})$, and lime $(\mathrm{CaO}) \ldots \ldots \ldots \ldots \ldots \ldots \ldots \ldots . \ldots . \ldots . \ldots$

Figure 2. Wet-bottom ash diffraction patterns nested from finest to coarsest size fractions (bottom up) as samples 18C, M18C, M16F, M15F, M14F, M13F. Phases include quartz (Q), mullite (M), hematite (H), magnetite (Ma), and

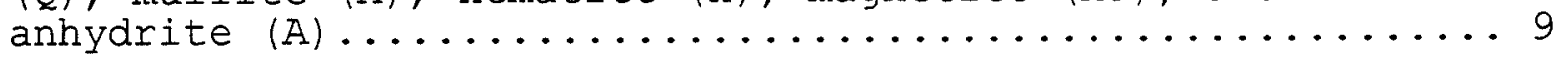

Figure 3. Secondary electron images of the coarse (A) and fine (B) fractions of the dry-bottom fly ash showing the spherical shapes and mottled surface textures.......... 11

Figure 4. Secondary electron images of coarse (A) and fine (B) fractions of the wet-bottom ash showing the spherical shapes and mottled surface textures. Some agglomeration

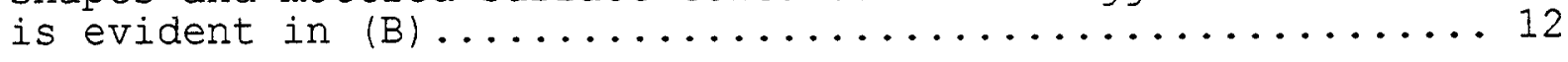

Figure 5. Microstructure of coarse-grained HIC fly ash after 24 hours of hydration illustrates the coarse, open network of hydration products, circular fly ash (FA) with reaction rims, abundant voids which are the black areas (V), large cement grains (C), calcium hydroxide $(\mathrm{CH})$, and quartz

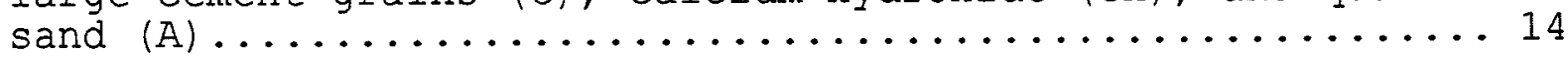

Figure 6. Microstructure of the fine-grained H3F fly ash illustrates the packing of the fly ash (FA) spheres between cement grains (C) and close packing to the sand (A). Common features are hydration products rimming fly ash and calcium hydroxide

Figure 7. Microstructures of $\mathrm{H} 1 \mathrm{C}$ (a) and H3F (b) mortars near a sand grain (A) after 60 days of curing appear more dense and uniform than those seen at $24 \mathrm{~h}$ (see Figs. 5 and 6 ). Some fly ash particles exhibit a reaction rim of hydration product and

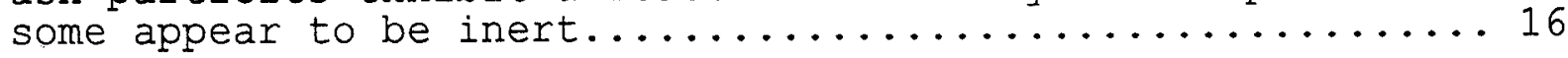




\subsection{INTRODUCTION}

Fly ash is a byproduct of combustion of coal in coal-fired powerplants through condensation and agglomeration of coal mineral matter that has been partially to completely melted. While mineral matter in coal is composed of clay minerals, quartz, calcite, and pyrite, fly ash is usually predominantly glass, with some remnant quartz and other crystalline compounds formed during the cooling of the melt. Most fly ashes are either pozzolanic or cementitious and they can be exploited to produce concretes with improved workability and improved durability. However, material variability and difficulties in predicting the performance of fly ash in concrete have tended to hinder rapid growth in its use. According to the American Coal Ash Association [1], fly ash production in 1992 totaled 44 metric tons, of which only 7 metric tons were used in concrete. The rest had to be disposed of at a significant cost to power plant companies, and to the detriment of the environment.

This study is part of a study of the material properties of fly ashes and other mineral admixtures to identify factors that control the performance of mineral admixtures in concrete. This study includes the determination of the kinetics of reactions, development of microstructure, and simulation modelling. The overall goal is understanding of how the material properties of fly ash affect the properties and durability of concrete. This report examines the composition of a set of fly ashes segregated by particle size, and comments on the effects of compositional and physical attributes on the performance of concrete.

Recent studies concluded that the performance of fly ash in concrete, as indicated by strength development and resistance to sulfuric acid, can be improved by either optimal control of the combustion conditions in the boiler, or beneficiation of the ash by removing the largest particles, or both $[2,3,4,5,6,7]$. If these findings can be shown to be of general validity, they should result in an increase in the use of fly ash in concrete. New options available for production of high-performance concrete and advancement of "green" concrete technology are likely to result in: a reduction in the energy embodied in concrete by reducing the amount of portland cement needed in concrete, with an associated reduction in the amount of carbon dioxide emitted in cement manufacture; a reduction in the volume of fly ash for disposal; and improved durability and rheological and performance properties of concrete. An improved understanding of the relationships among the chemical and physical properties of fly ash and its performance in concrete is necessary to establish a technical basis for predicting the performance of fly ashcontaining concrete. 
Samples of fly ash produced by burning the same coal in different boiler types were provided by the New Jersey Institute of Technology [6]. Size-fractionated subsamples of these ashes produced concretes of increased strength with ash fineness. Testing of concretes with $25 \%$ replacement, by mass, of cement recorded strengths of $110 \%$ and $93 \%$ of a control concrete, respectively, for the fine and coarse fractions of wet-bottom boiler ashes and $106 \%$ and $89 \%$ of the control concrete, respectively, for the dry-bottom ashes. The purpose of this study was to examine the mineralogy and size distributions of the fly ashes, and relate them to the strength characteristics and microstructures of mortars incorporating the ashes.

\subsection{POZZOLANIC REACTIONS}

Pozzolanic materials are typically high in $\mathrm{SiO}_{2}$ and $\mathrm{Al}_{2} \mathrm{O}_{3}$, low in $\mathrm{CaO}$, with little or no reactivity when immersed in water. However, with water and $\mathrm{Ca}(\mathrm{OH})_{2}$, fly ashes generally react to form a calcium silicate hydrate [8]. Fly ash, along with consolidated volcanic ash, and silica fume, are pozzolanic mineral admixtures with important applications in the production of concrete. Each of these mineral admixtures is comprised of a glassy phase and lessor amounts of crystalline phases.

Pietersen [7] states that the glassy phase is the reactive phase in fly ash, and that its dissolution rate increases with $\mathrm{pH}$ above 9 in environments such as the pore solution of concrete. In addition, Bijen and Pietersen [9] indicate other factors influencing the reactivity of fly ash are: alkalinity of the pore solution due to $\mathrm{K}^{+}$and $\mathrm{Na}^{+}$ions from the ash or the cement; temperature influence on the pore water hydroxide ion concentration; and an increase in alkalinity with a decrease in water/cementitious materials ratio.

Kokubu [10] concluded that the pozzolanic reactivity of fly ash is primarily related to the surface area of the glassy phase. The surface area/reactivity relationship was also demonstrated by Pieterson [7] in a study of fractionated fly ashes where he concluded that there were no significant dissolution differences in the glass phase under conditions of different temperature and different $\mathrm{pH}$ levels.

Beneficial effects of fly ash in concrete include increased workability, or reduction in water requirements for a similar workability [11]. This is often attributed to what is termed the "ball bearing" effect of the spherical fly ash particles, though it has also been attributed in part to a dispersion of the cement floc structure. Bijen and Pietersen [9] attribute mineral admixture benefits not only to their chemical reactivity, but also to physical and physicochemical effects such as improved dispersion of cement particles; nucleation sites for hydration products; acceleration of the cement dissolution; and, due to 
their fine particle size, a filler effect. The replacement of cement by fly ash reduces the heat of hydration and temperature rise reducing the possibility of cracking due to thermal stresses. Increased durability of fly ash concretes exposed to sulfate waters, sea water, and acids is achieved through a reduction in permeability, a decrease in volume fraction of calcium hydroxide, and an increase in volume fraction of calcium silicate hydrates.

ASTM C 311 [12] provides chemical and physical test methods for the characterization of fly ash, and ASTM C 618 [13] provides chemical and physical criteria for classification, including size and strength requirements. This classification recognizes two distinct fly ash types (Table 1). Class $F$ fly ash is derived primarily from bituminous and anthracite coals and exhibits pozzolanic properties. Class $\mathrm{C}$ fly ash, derived from subbituminous or lignitic coals, is higher in calcium oxide and exhibits both pozzolanic and cementitious properties. Fly ashes analyzed in our study were Class $F$ ashes from bituminous coals.

\subsection{EXPERIMENTAL PROCEDURES}

Two fly ashes were provided by the New Jersey Institute of Technology (NJIT), one from a wet-bottom boiler and one from a dry-bottom boiler, each fractionated into six size ranges via air separation. These ashes represent the combustion products of the same coal burned under different operating conditions. Thermocouples within the boilers registered combustion chamber temperatures of $1500{ }^{\circ} \mathrm{C}$ and $1400{ }^{\circ} \mathrm{C}$ respectively for the dry and wet-bottom boilers [14]. These samples were subsampled for X-ray powder diffraction analysis, scanning electron microscopy (SEM) examination, and for preparation of test mortars.

Table 1. Chemical Requirements for Fly Ashes According to ASTM C 618 [13].

\begin{tabular}{|c|c|c|}
\hline Requirement & Class $\mathrm{F}$ & Class \\
\hline 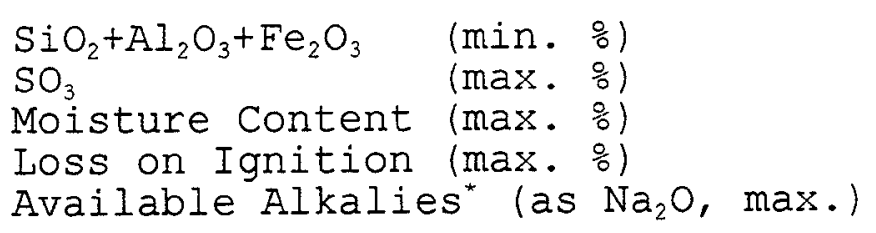 & $\begin{array}{r}70.0 \\
5.0 \\
3.0 \\
6.0 \\
1.5\end{array}$ & $\begin{array}{r}50.0 \\
5.0 \\
3.0 \\
6.0 \\
1.5\end{array}$ \\
\hline
\end{tabular}




\subsection{X-Ray Powder Diffraction (XRD) Analysis}

Difficulties in assigning reliable compositions to each phase render estimation of phase abundance compositions from $X$-ray fluorescence data unreliable. XRD provides direct information on the mineralogical composition of the fly ash as each crystalline compound produces a unique diffraction pattern. Phase identifications are made by comparing the diffraction pattern of the mixture to a database of pure phase reference patterns published by the International Center for Diffraction Data [15].

Diffraction patterns for each ash were collected using $\mathrm{Cu} \mathrm{K} \alpha$ radiation at $40 \mathrm{kV}$ and $40 \mathrm{~mA}$ with a graphite monochromator at 50 steps/degree and 3 seconds/step count time. Approximately $5 \mathrm{~g}$ of each ash sample were ground to reduce particle sizes to less than $10 \mu \mathrm{m}$ and to fracture the spheres to improve the sample packing characteristics. Bulk ash patterns were scanned from $4^{\circ}$ to $65^{\circ}$ 2 -theta for qualitative phase identifications, and two replicate scans from $20^{\circ}$ to $45^{\circ}$ 2-theta for semi-quantitative analysis.

The intensity of an individual phase diffraction pattern in a mixture is proportional to its concentration. Therefore, phase concentrations can be estimated through use of an internal standard and calibration that relates the peak intensity ratio of each phase and internal standard to their mass fraction ratio [16].

Following the quantitative powder diffraction procedure developed by McCarthy, Thedchanamoorthy and co-workers $[17,18,19]$, ten percent rutile was added to each sample as an internal standard, and homogenized using a mortar and pestle. The Reference Intensity Ratio (RIR) [20] method was used to relate peak intensity ratio to the mass fraction of each phase in the mixture. RIR values determined for a similar diffractometer [18] were used for this study. Calibration constants (RIRs) can vary significantly depending on actual phase compositions. The precision of the analysis is estimated [18] as $\pm 10 \%$ for strongly diffracting phases such as quartz, and $\pm 25 \%$ for weakly diffracting phases such as mullite. These analyses, therefore, should be considered semi-quantitative. However, inter-sample variations will be reflected by the diffraction intensities.

Non-crystalline components, or the "glass", are comprised of aluminosilicate glassy material modified by inclusion of $\mathrm{Na}_{2} \mathrm{O}$, $\mathrm{K}_{2} \mathrm{O}, \mathrm{MgO}, \mathrm{CaO}$, and $\mathrm{FeO}[7]$. This glass content is reflected by a broad "hump" in the diffraction pattern. While the glass fractions cannot be quantified directly, XRD analyses $[7,18,19]$ of fly ashes and slags quantified the crystalline material and considered the difference, after subtraction of the loss on ignition, as being the mass fraction of glass. 


\subsection{Mortars with Fly Ash as a Partial Cement Replacement}

A mixture with $25 \%$, by mass, replacement of cement by fly ash, ASTM Type I portland cement with a sand/cement ratio of $3: 1$, by mass, and a water/cementitious material (cement + ash) ratio of 0.50 , by mass, was used in preparing mortars for microstructural studies. The mortars were hand mixed in a small bowl using a rubber spatula for one minute, allowed to rest for one minute while the bowl walls were scraped, mixed for an additional minute and cast in $25 \mathrm{~mm}$ diameter plastic cylinders. The cylinders were allowed to cure in sealed plastic bags maintained at about $23{ }^{\circ} \mathrm{C}$ and $100 \%$ relative humidity. Each mortar was sampled after 24 hours, 7 days, and 60 days curing for compositional and microstructural studies.

\subsection{RESULTS AND DISCUSSION}

\subsection{Chemical Analysis}

Chemical analyses of the ashes and their subsamples by X-ray fluorescence data as determined by Jaturapitakkul [6] are presented in Table 2. The wet-bottom ash and its sized subsamples have higher $\mathrm{SO}_{3}, \mathrm{CaO}, \mathrm{K}_{2} \mathrm{O}, \mathrm{Na}_{2} \mathrm{O}$, and $\mathrm{MgO}$ contents, while the dry-bottom ashes have a greater $\mathrm{SiO}_{2}$ and greater, and perhaps more variable, loss on ignition (LOI). The alkali levels of the wet-bottom ash and the fractionated subsamples would not allow their use in concretes with reactive aggregates per the ASTM C 618 [13] optional alkali requirement. Other trends noted in Table 2 include a slight increase in $\mathrm{SiO}_{2}$ content with particle diameter and, for the dry ashes, a decrease in LOI with increasing particle diameter. The LOI value reflects the mass of carbon from unburned coal remaining in the fly ash. This remnant carbon can discolor concrete in which the ash is used and cause difficulties in selecting the correct doses of chemical admixtures [8]. 
Table 2. Chemical Compositions, Loss-On-Ignition, and Fineness for Size-Fractionated Fly Ashs as determined by Jaturapitakkul [6] .

\begin{tabular}{|c|c|c|c|c|c|c|c|c|c|c|c|}
\hline Sub. ${ }^{\mathrm{T}}$ & $\% \mathrm{SO}_{3}$ & $\stackrel{\circ \mathrm{SiO}_{2}}{ }$ & $\mathrm{Al}_{2} \mathrm{O}_{3}$ & $\% \mathrm{Fe}_{2} \mathrm{O}_{3}$ & \% $\mathrm{CaO}$ & $\div \mathrm{K}_{2} \mathrm{O}$ & $\frac{\circ}{\partial} \mathrm{MgO}$ & $\frac{\mathrm{Na}}{2} \mathrm{O}$ & 으OI & $\begin{array}{l}\text { Blaine } \\
\mathrm{cm}^{2} / \mathrm{g}\end{array}$ & $\begin{array}{cc}\text { Mean Dia. } \\
{\mu \mathrm{m}^{2}}^{2}\end{array}$ \\
\hline
\end{tabular}

Dry-Bottom Boiler Ash

\begin{tabular}{|c|c|c|c|c|c|c|c|c|c|c|c|}
\hline $\begin{array}{l}\mathrm{H} 3 \mathrm{~F} \\
\mathrm{H} 5 \mathrm{~F} \\
\mathrm{H} 6 \mathrm{~F} \\
\mathrm{H} 10 \mathrm{~F} \\
\mathrm{H} 11 \mathrm{~F} \\
1 \mathrm{C}\end{array}$ & $\begin{array}{l}1.69 \\
1.53 \\
1.09 \\
0.72 \\
0.53 \\
0.39\end{array}$ & $\begin{array}{l}49.89 \\
50.27 \\
51.40 \\
51.98 \\
51.27 \\
53.01\end{array}$ & $\begin{array}{l}26.94 \\
26.74 \\
26.54 \\
26.23 \\
26.28 \\
26.50\end{array}$ & $\begin{array}{l}5.43 \\
5.30 \\
4.91 \\
4.44 \\
4.42 \\
5.66\end{array}$ & $\begin{array}{l}2.99 \\
2.95 \\
2.72 \\
2.28 \\
2.02 \\
1.90\end{array}$ & $\begin{array}{l}1.76 \\
1.74 \\
1.71 \\
1.60 \\
1.55 \\
1.61\end{array}$ & $\begin{array}{l}0.99 \\
0.93 \\
0.74 \\
0.54 \\
0.49 \\
0.56\end{array}$ & $\begin{array}{l}0.33 \\
0.33 \\
0.31 \\
0.29 \\
0.26 \\
0.24\end{array}$ & $\begin{array}{l}4.97 \\
4.10 \\
3.12 \\
2.52 \\
2.04 \\
1.46\end{array}$ & $\begin{array}{l}7844 \\
6919 \\
4478 \\
2028 \\
1744 \\
1079\end{array}$ & $\begin{array}{r}2.11 \\
2.66 \\
5.66 \\
12.12 \\
15.69 \\
39.45\end{array}$ \\
\hline Bulk & 0.98 & 52.25 & 26.72 & 5.43 & 2.41 & 1.67 & 0.69 & 0.28 & 2.75 & 3235 & 13.73 \\
\hline
\end{tabular}

Wet-Bottom Boiler Ash

\begin{tabular}{|c|c|c|c|c|c|c|c|c|c|c|c|}
\hline $\begin{array}{l}\text { M13F } \\
\text { M14F } \\
\text { M15F } \\
\text { M16F } \\
\text { M18F } \\
\text { M18C }\end{array}$ & $\begin{array}{l}3.81 \\
3.47 \\
3.33 \\
3.05 \\
2.94 \\
2.40\end{array}$ & $\begin{array}{l}38.93 \\
39.72 \\
40.25 \\
40.65 \\
41.56 \\
43.25\end{array}$ & $\begin{array}{l}24.91 \\
25.08 \\
25.02 \\
24.92 \\
24.47 \\
23.31\end{array}$ & $\begin{array}{l}12.89 \\
13.02 \\
13.12 \\
13.26 \\
14.21 \\
17.19\end{array}$ & $\begin{array}{l}6.85 \\
6.71 \\
6.60 \\
6.55 \\
6.58 \\
7.38\end{array}$ & $\begin{array}{l}2.10 \\
2.11 \\
2.11 \\
2.09 \\
2.01 \\
2.00\end{array}$ & $\begin{array}{l}1.55 \\
1.50 \\
1.47 \\
1.41 \\
1.40 \\
1.30\end{array}$ & $\begin{array}{l}1.31 \\
1.31 \\
1.30 \\
1.26 \\
1.17 \\
0.88\end{array}$ & $\begin{array}{l}2.67 \\
1.94 \\
1.88 \\
2.06 \\
1.94 \\
2.55\end{array}$ & $\begin{array}{r}11241 \\
9106 \\
7471 \\
5171 \\
3216 \\
1760\end{array}$ & $\begin{array}{r}1.84 \\
2.50 \\
3.09 \\
5.54 \\
9.84 \\
29.25\end{array}$ \\
\hline Bulk & 3.13 & 41.54 & 27.74 & 14.83 & 6.89 & 2.07 & 1.43 & 1.17 & 2.05 & 5017 & $6: 41$ \\
\hline
\end{tabular}

${ }^{1}$ Subsample identification

${ }^{2}$ Calculated from the Blaine specific surface area 


\subsection{Mineralogy of Ash}

Mineral matter in coal includes detrital material such as clays and quartz that was washed into the coal-forming swamp and authigenic minerals including calcite and pyrite formed after the coal formed. The compositions of the end products after combustion, the fly ash and bottom ash, are dependent on both the mineral composition of each coal particle and boiler conditions. Alumino silicates such as clays may melt or decompose to form a glass or mullite; carbonates including calcite, dolomite, ankerite, and siderite decompose releasing $\mathrm{CO}_{2}$ and forming lime, and periclase; sulphides such as pyrite oxidize and lose $\mathrm{SO}_{2}$ forming sulfates, and iron oxides such as hematite and magnetite; chlorides volatilize as $\mathrm{NaCl}$ and $\mathrm{KCl}$; and quartz generally remains unaltered [7].

Diffraction patterns of wet- and dry-bottom boiler ashes are presented in Figures 1 and 2 and illustrate the similarity between each ash and each ash size fraction. Differences in peak intensity reflect differences in phase concentration of the fine (lower patterns) and coarse (upper patterns) fly ash fractions. Crystalline compounds identified by $\mathrm{X}$-ray powder diffraction include quartz, mullite, hematite, spinel (magnetite), anhydrite, and lime.

Examination of the diffraction patterns and Table 3 indicates a decrease in crystalline phases with fineness. Glassy fractions range from 75\% to 85\% with the lower mass fractions found in the coarsest size fractions. Compositions of both ash sets are very similar with the wet ash exhibiting a slightly greater amount of hematite, magnetite, and anhydrite and slightly less mullite. Lime (CaO) was identified in the coarsest two fractions of the wet ash.

Table 3. XRD phase fraction estimates for wet and dry-bottom boiler fly ash expressed as mass percent.

\begin{tabular}{|c|c|c|c|c|c|c|c|}
\hline$\overline{\text { Ash }}$ & Quartz & Mullite & Magnetite & Hematite & Anhydrite & $\mathrm{CaO}$ & Glass \\
\hline \multicolumn{8}{|c|}{ Dry-Bottom Boiler Ash } \\
\hline $\mathrm{H} 3 \overline{\mathrm{E}}$ & 2 & 9 & 1 & - & 1 & - & 82 \\
\hline H5F & 2 & 9 & 1 & - & 1 & - & 83 \\
\hline $\mathrm{H} 6 \mathrm{~F}$ & 3 & 10 & 1 & $T ?$ & 1 & - & 82 \\
\hline H1OF & 4 & 13 & 1 & - & 1 & - & 77 \\
\hline $\mathrm{H} 11 \mathrm{~F}$ & 3 & 14 & 1 & - & 1 & - & 78 \\
\hline $\mathrm{H} 1 \mathrm{C}$ & 3 & 16 & 1 & - & 1 & - & 74 \\
\hline \multicolumn{8}{|c|}{ Wet-Bottom B } \\
\hline $\mathrm{M} 13 \mathrm{~F}$ & 1 & 6 & 2 & 1 & 2 & - & 85 \\
\hline $\mathrm{M} 14 \mathrm{~F}$ & 2 & 6 & 3 & 1 & 2 & - & 84 \\
\hline M15E & 2 & 6 & 2 & 1 & 2 & - & 85 \\
\hline $\mathrm{M} 16 \mathrm{~F}$ & 4 & 4 & 2 & 2 & 2 & - & 84 \\
\hline M1 8C & 3 & 10 & 5 & 3 & 2 & 1 & 74 \\
\hline $18 \mathrm{C}$ & 4 & 9 & 3 & 3 & 2 & 1 & 75 \\
\hline $\mathrm{T}=$ & race & & & & & & \\
\hline
\end{tabular}




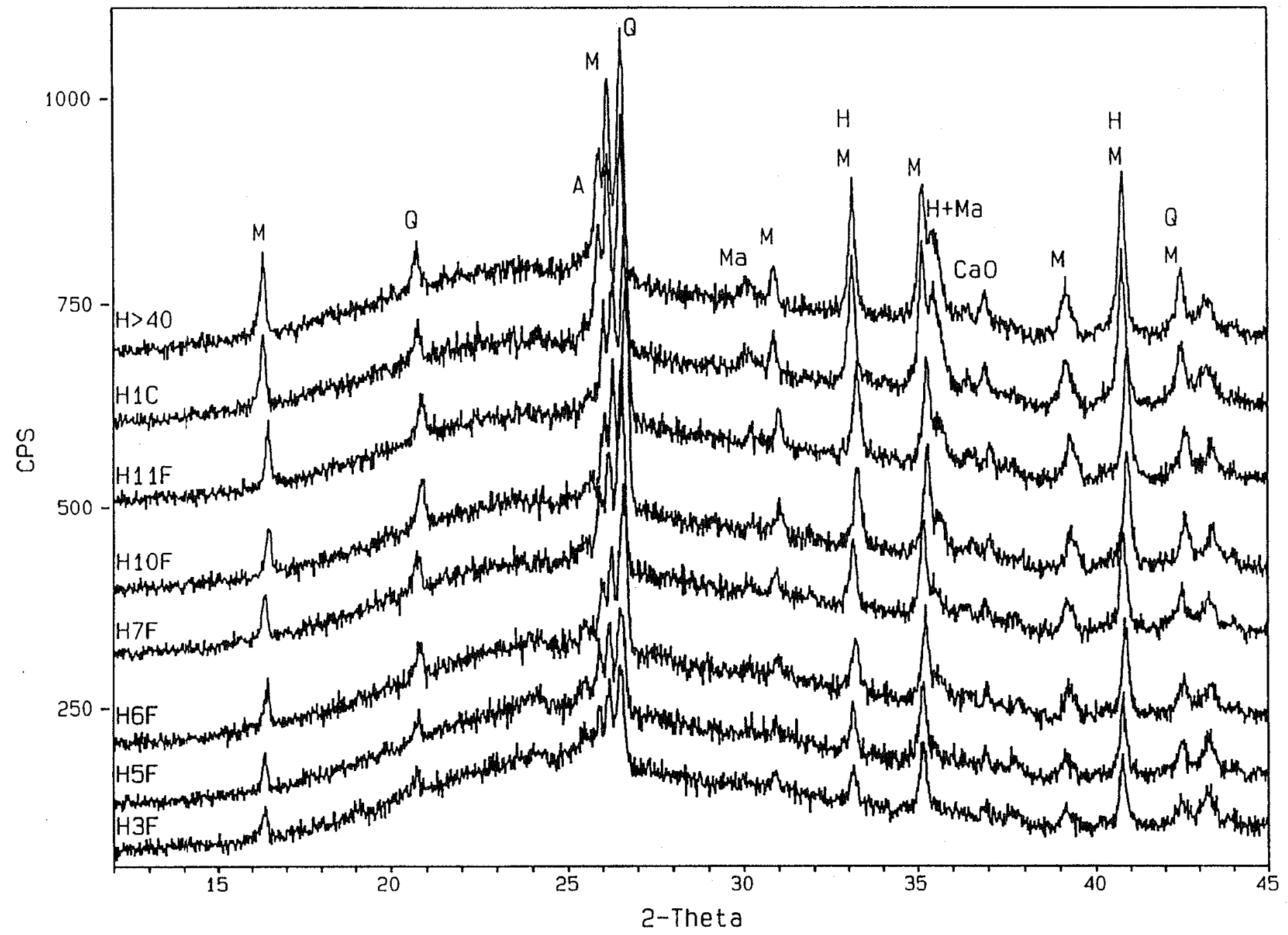

Figure 1. Dry-bottom ash diffraction patterns nested from finest to coarsest size fractions (bottom up) as samples H3F, H5F, H6F, H1OF, H11F, H1C, and H>40. Phases include quartz (Q), mullite (M), hematite (H), magnetite (Ma), anhydrite (A), periclase (P), and lime (CaO). 


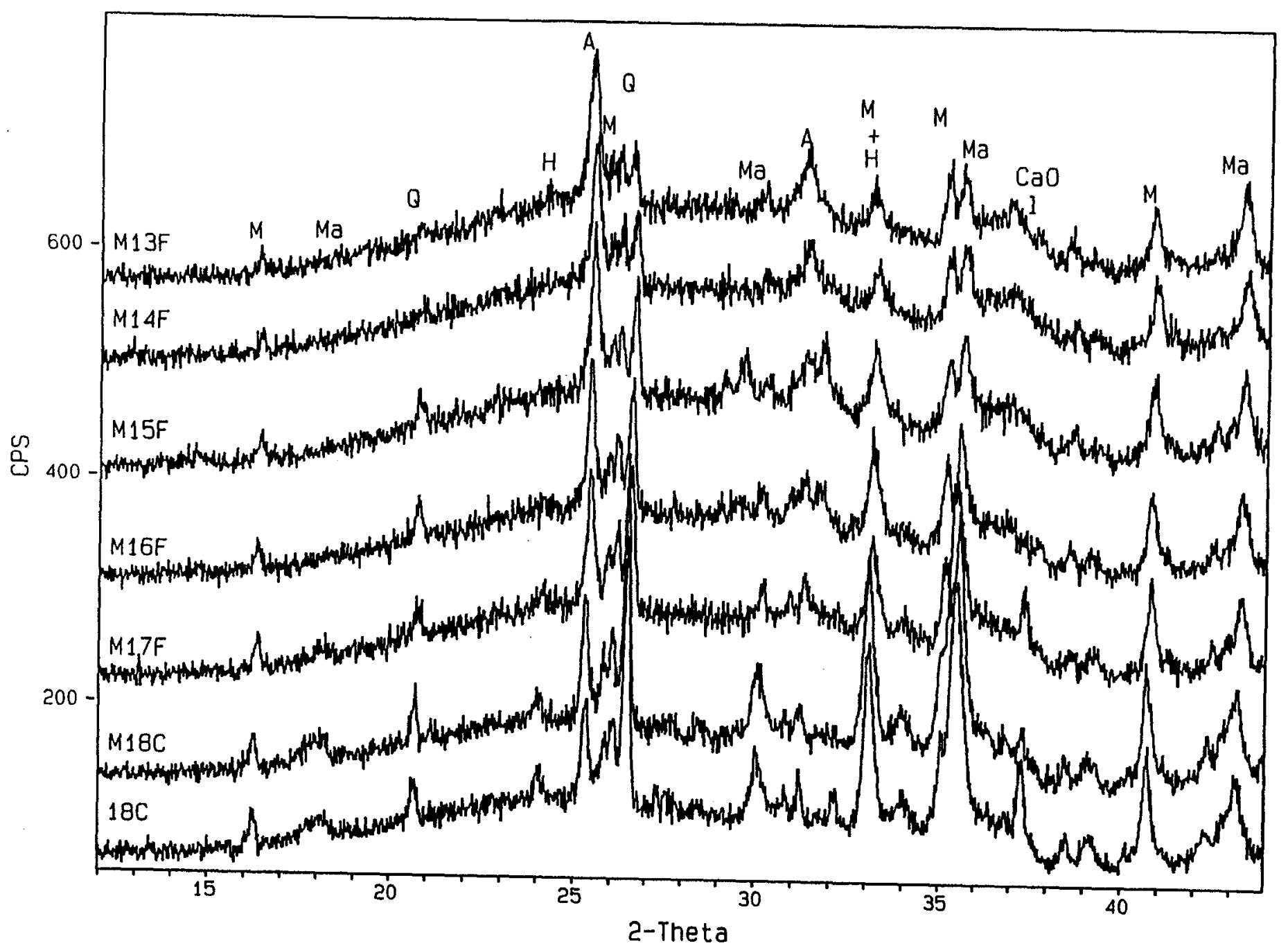

Figure 2. Wet-bottom ash diffraction patterns nested from finest to coarsest size fractions (bottom up) as samples 18C, M18C, M16f, M15F, M14F, M13F. Phases include quartz (Q), mullite (M), hematite $(\mathrm{H})$, magnetite $(\mathrm{Ma})$, and anhydrite $(\mathrm{A})$. 
Quantitative estimates of the glass contents indicate an increase with fineness. Helmuth [11] reports similar findings in a study performed by the U.S. Army Corps of Engineers. This finding is duplicated by Pieterson [7] who attributed the glass content increases to the more rapid cooling of the smaller particles. Both ash sets exhibit an increase in quartz and muliite content with increase in particle diameter.

$\mathrm{X}$-ray powder diffraction has also been used to characterize the poorly crystallized glass fraction of fly ashes. Diamond [21] demonstrated a linear correlation between the cao content and the glass phase diffraction maxima for fly ashes of up to $20 \%$ CaO. Higher CaO fly ash glass maximum occur at greater 2-theta angles indicative of a calcium aluminate glasses which he expected to be more reactive. Pietersen [7] reported studies relating the glass "hump" maximum to glass type noting that the low angle humps in the range of $22-24^{\circ} 2$-theta are characteristic of highly polymerized silicious glasses. Maxima in the 30-34\% 2 -theta range correspond to modified, highly depolymerized glasses. All diffraction patterns illustrated in Figures 1 and 2 exhibit an amorphous hump maximum in the $24^{\circ}$ to $25^{\circ}$-theta region. The location of the diffraction maximum indicates a highly polymerized, silicious glass typical of a low-CaO fly ash [7,21]. This also indicates little difference in the amorphous component of the different particle size fractions.

Pietersen [7] notes that numerous researchers have found a correlation among $\mathrm{K}_{2} \mathrm{O}, \mathrm{Na}_{2} \mathrm{O}$, and glass content. In an attempt to provide a measure of potential pozzolanic reactivity [7], Pietersen defined the Pozzolanic Potential Index (PPI), where $\mathrm{PPI}=10 * \mathrm{~K}_{2} \mathrm{O}$ mass\%/ $\mathrm{Al}_{2} \mathrm{O}_{3}$ mass\%. Data for the ashes in our study show an increase in these values only between the bulk ash and the fractionated subsamples.

\subsection{Morphological Characteristics of Fly Ash}

Three distinct morphologies have been observed in fly ashes: well-rounded, solid spheres; well-rounded hollow spheres with thin walls termed cenospheres; and plerospheres which are cenospheres containing numerous smaller spheres within their hollow cavity.

Figures 3 and 4 present SEM images of the coarsest and finest size fractions from the two boiler conditions. There do not appear to be any distinct morphological differences between the two sample sets. The fine fraction fly ash particles are typically well-rounded, solid spheres, and the larger particles within the larger size fraction subsamples contain a few particles up to $0.5 \mathrm{~mm}$ with cenospheres common and an occasional plerosphere. Some of the larger particles are vesicular. Pieterson [7] attributes the origin of the vesicles to generation of gases and vapors such as $\mathrm{CO}, \mathrm{CO}_{2}, \mathrm{SO}_{2}$, and $\mathrm{H}_{2} \mathrm{O}$. Remnants of unburned coal are often found as rounded, somewhat less spherical vesicular grains. 




(a)

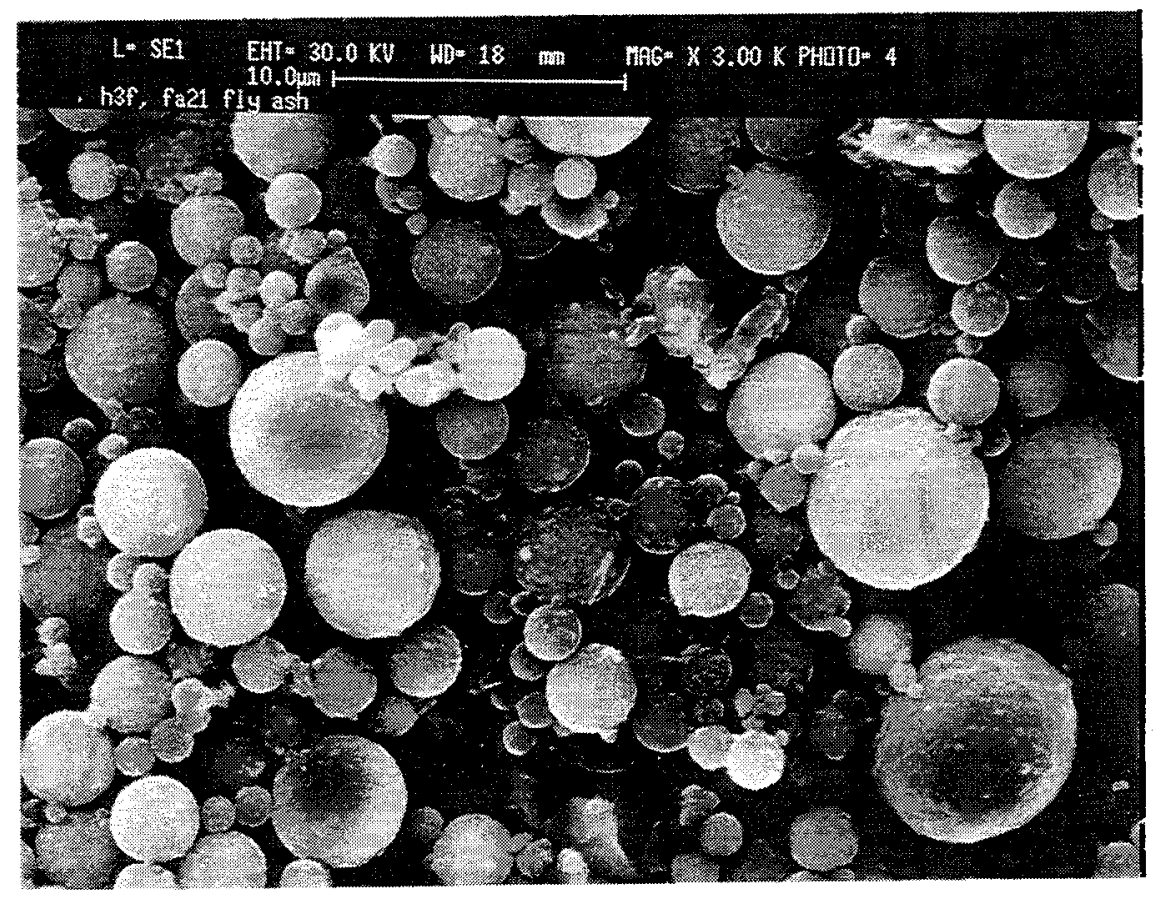

(b)

Figure 3. Secondary electron images of the coarse (a) and fine (b) fractions of the dry-bottom ash showing the spherical shapes and mottled surface textures. 


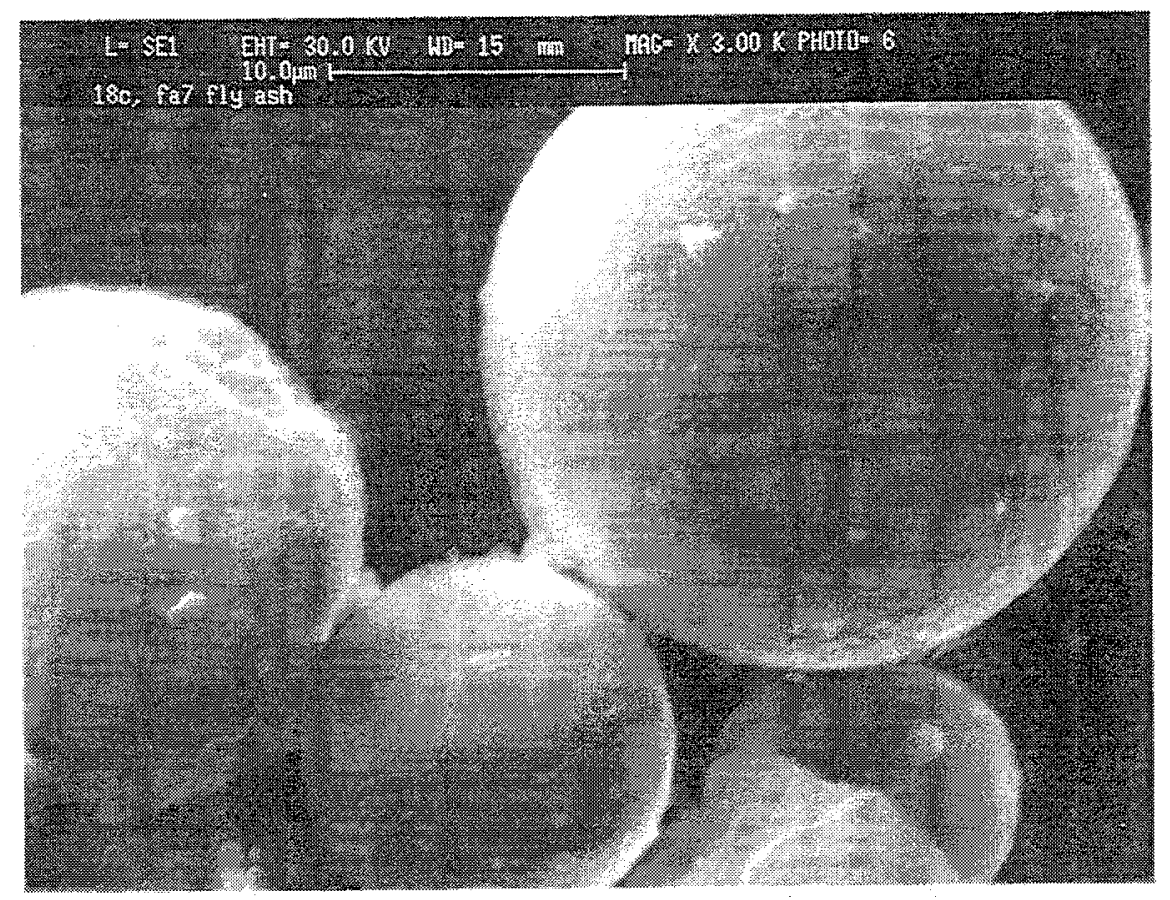

(a)

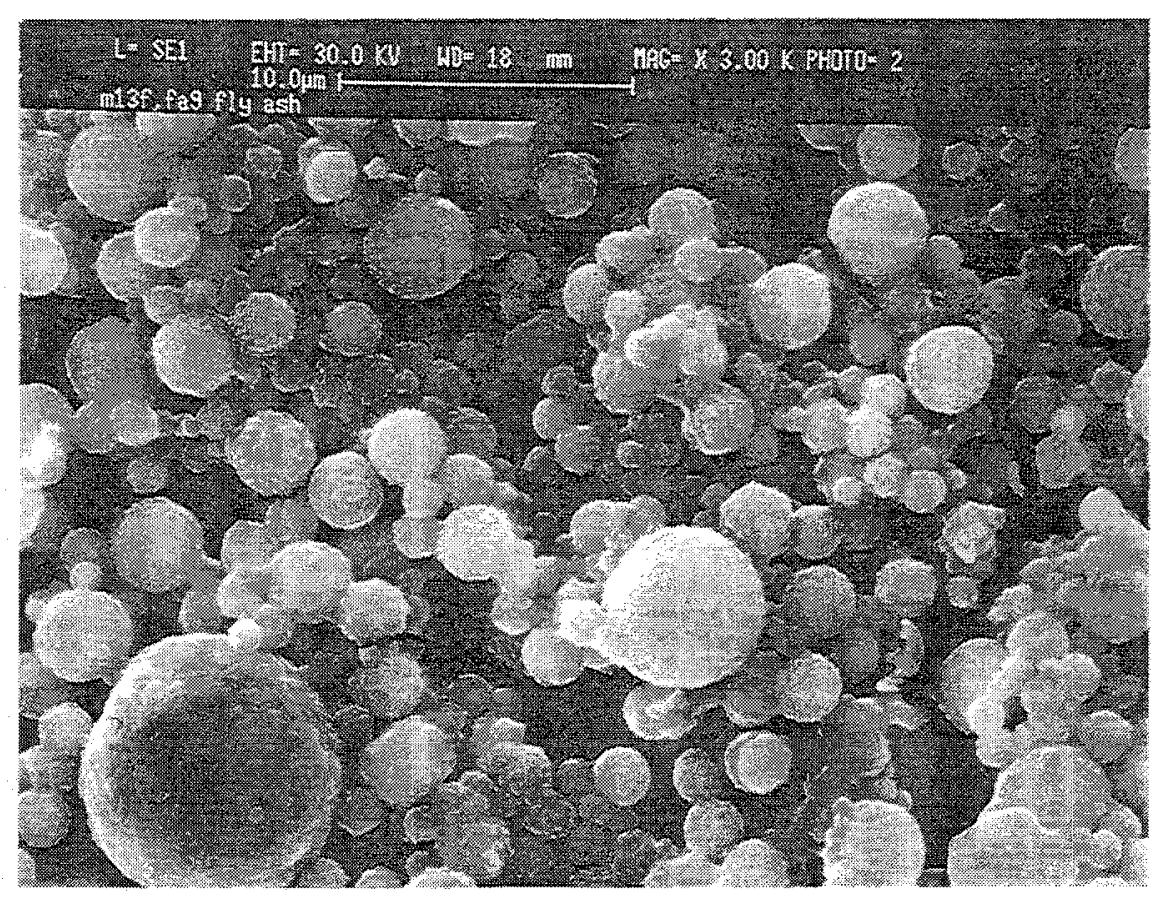

(b)

Figure 4. Secondary electron images of the coarse (a) and fine (b) fractions of the wet-bottom ash showing the spherical shapes and mottled surface textures. Some agglomeration is evident in (b) . 


\subsection{Mortars Containing Fly Ash}

Mortars prepared with four ash samples representing the fine and coarse extremes were examined at 24 hours, 7 days, and 60 days of curing time at $100 \%$ relative humidity. Each mortar was subsampled at 24 hours, 7 days, and 60 days for SEM imaging and XRD. XRD powders were prepared by disaggregating and sieving the mortar through a 200 mesh sieve $(75 \mathrm{\mu m})$ to remove the sand fraction.

Images of the hardened mortar microstructure after 24 hours curing time are presented in Figures 5 and 6 for samples $\mathrm{H} 1 \mathrm{C}$ and H3F from the dry-bottom boiler ash. The calcium silicate hydrate gel (C-S-H) has formed a complex framework that will eventually form the bulk of the matrix of the mortar. Void space, filled by resin during sample preparation, appears black. An aggregate particle appears in the upper portion of the images.

Differences between bulk paste and microstructure within $100 \mu \mathrm{m}$ of the aggregate, the interfacial zone, are not readily apparent at this age. Unhydrated cement grains appear as bright angular fragments rimmed by $\mathrm{C}-\mathrm{S}-\mathrm{H}$. Calcium hydroxide (CH) occurs as both elongated crystals where space for growth was available and as masses precipitated within the voids in the $\mathrm{C}-\mathrm{S}-\mathrm{H}$ network. Fly ash spheres in cross section appear circular and exhibit a thin layer of hydration product on their rims. The cross-sections of the ash reveal some compositional heterogeneity, with the bright iron-rich spheres containing magnetite or hematite. Subtle intensity differences between the darker spheres reflect variations in calcium and potassium content. Packing ability of the coarse and fine fly ashes may be contrasted in figures 5 and 6 , with the finer ash filling the regions between the aggregate and cement grains resulting in a more uniform microstructure.

Figure 7 illustrates the microstructure of both of these mortars after 60 days of hydration. These mortars exhibit a much more dense and uniform paste microstructure extending to where the paste bonds to the aggregate. Reaction rims appearing around some of the fly ash particles indicate that some of the pozzolanic hydration product forms in situ while other spheres exhibit a loss of material as indicated by a void between the sphere and paste. Calcium hydroxide, and unreacted fly ash, is present in both samples indicating that the pozzolanic reaction is far from complete. 


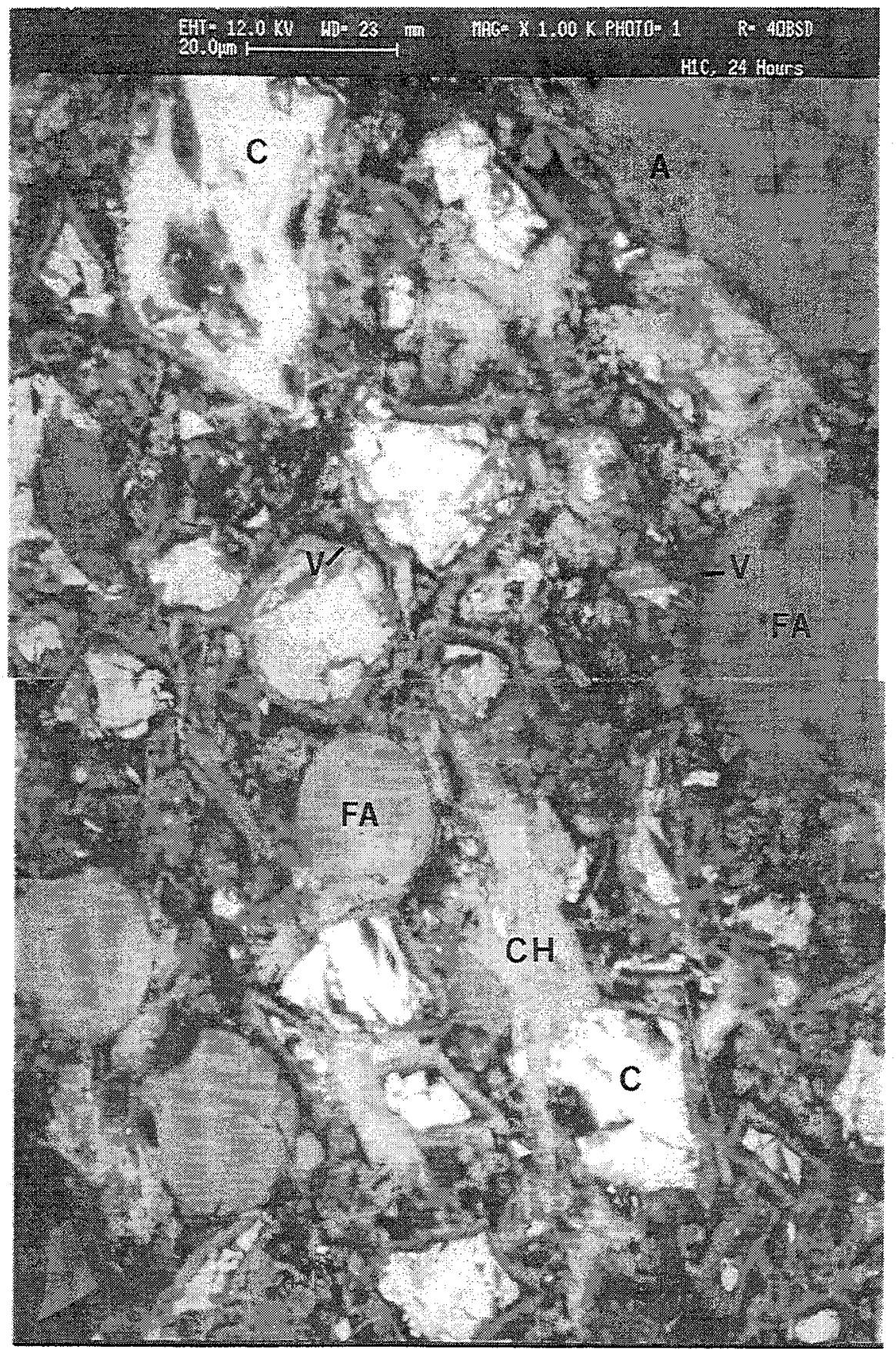

Figure 5. Microstructure of coarse-grained HlC fly ash after 24 hours of hydration illustrates the coarse, open network of hydration products, circular fly ash (FA) with reaction rims, abundant voids which are the black areas (V), large cement grains (C), calcium hydroxide $(\mathrm{CH})$, and quartz sand $(\mathrm{A})$. 


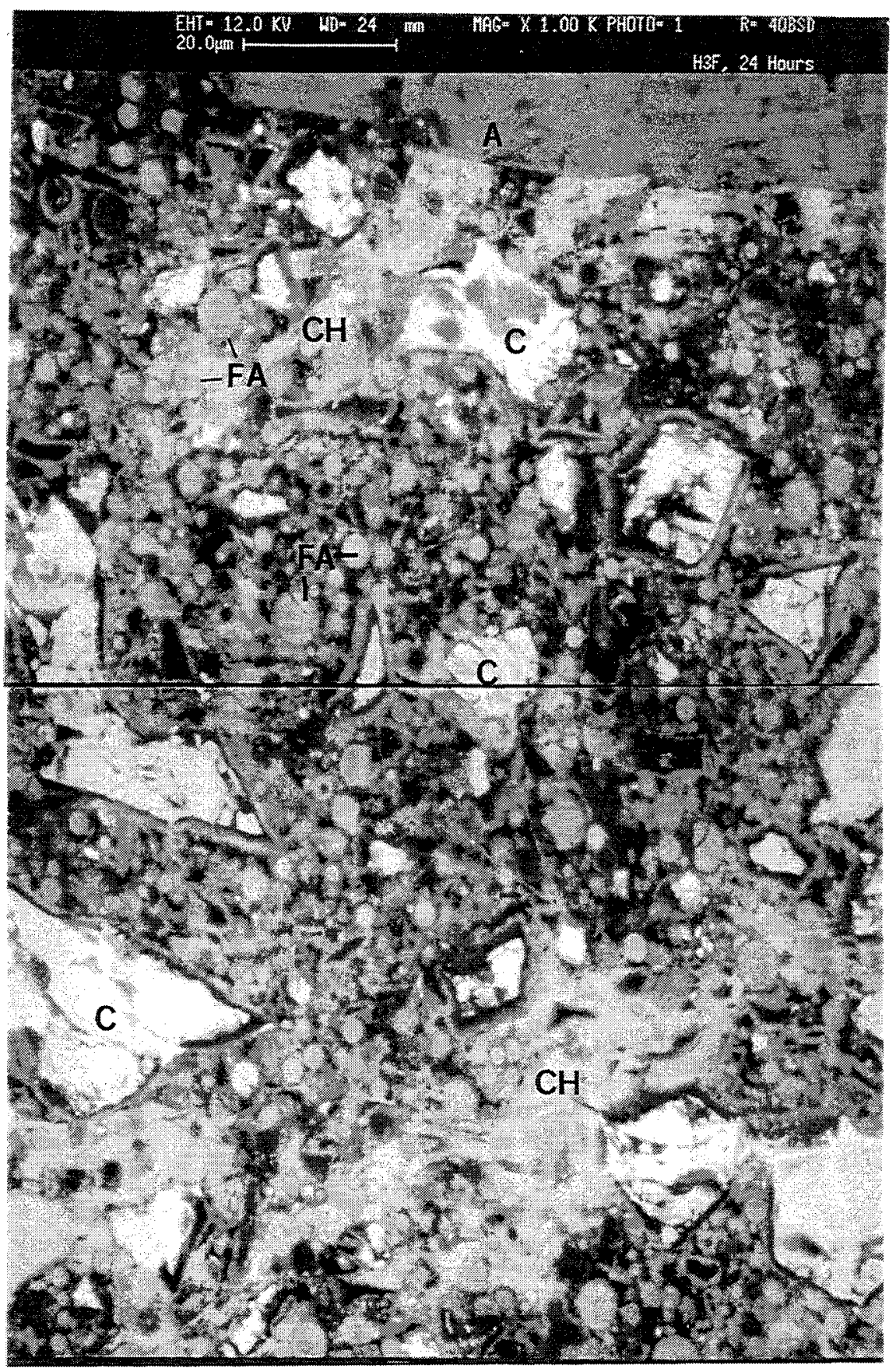

Figure 6. Microstructure of the fine-grained H3F fly ash illustrates the packing of the fly ash (FA) spheres between cement grains (C) and close packing to the sand (A). Common features are hydration products rimming fly ash and calcium hydroxide $(\mathrm{CH})$. 


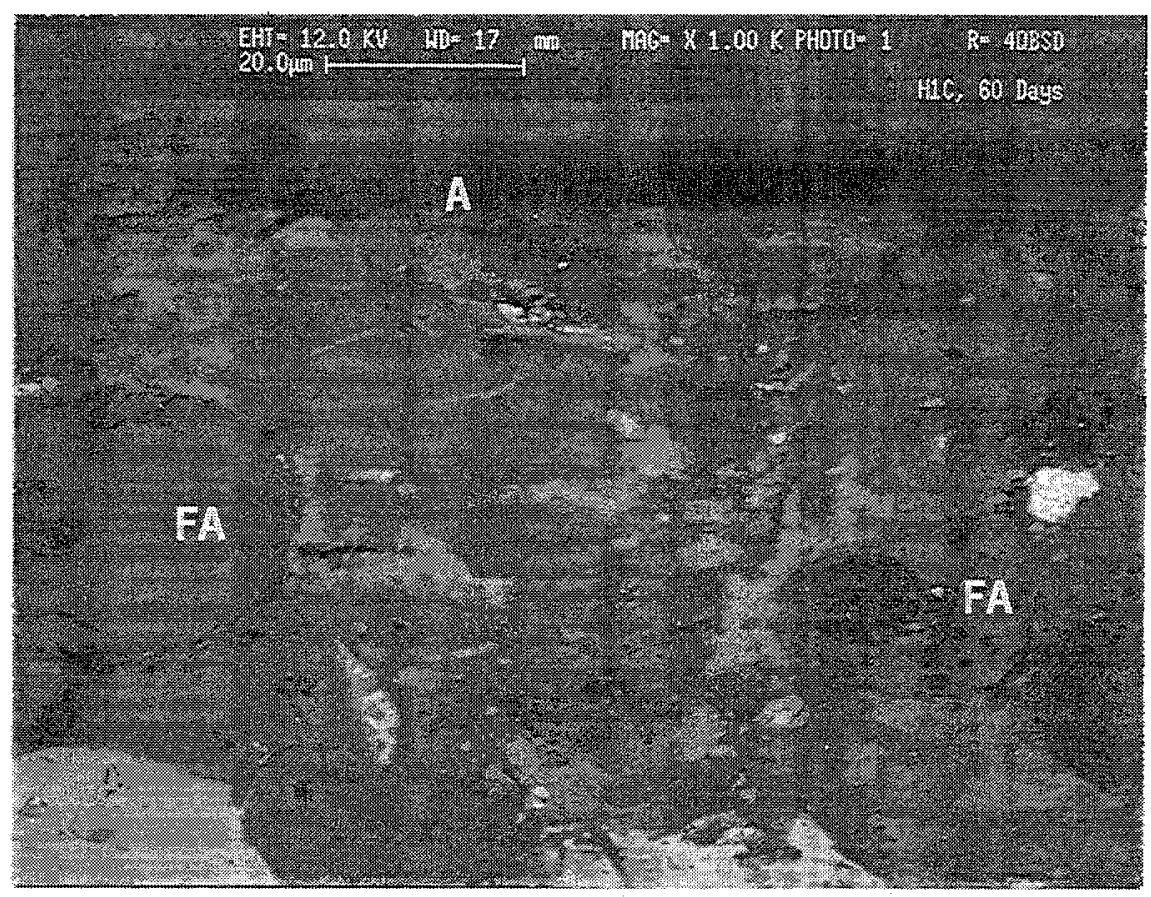

(a)

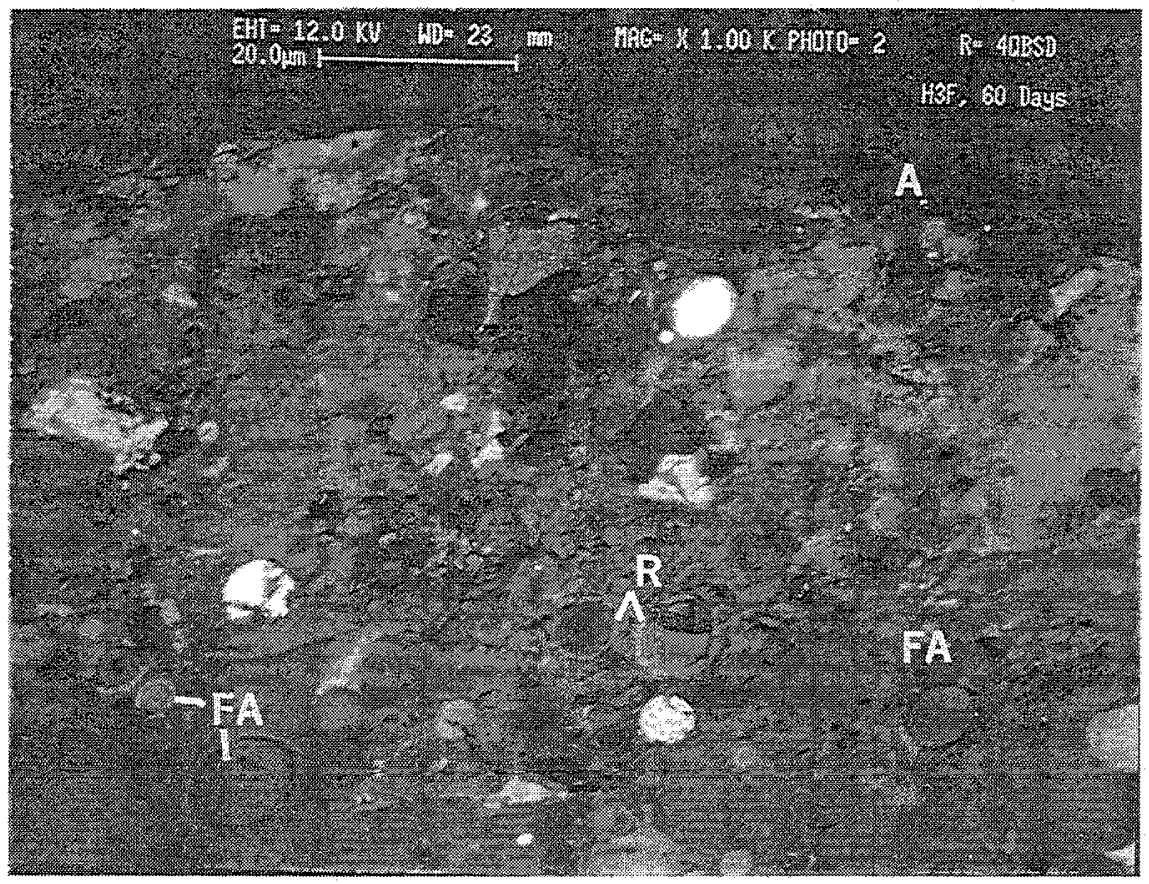

(b)

Figure 7. Microstructures of HIC (a) and H3E (b) mortars near a sand grain (A) after 60 days of curing appear more dense and uniform than those seen at $24 \mathrm{~h}$ (see Figs. 5 and 6). Some fly ash (EA) particles exhibit a reaction rim of hydration product, and some appear to be inert. 


\subsection{SUMMARY}

Fly ash continues to receive interest as a mineral admixture for concrete, the full potential of which has not yet been exploited. Its use provides numerous benefits to concrete producers and users. Among the benefits of partial replacement of cement in the concrete are: beneficial use of a waste material; reduction of the energy necessary to produce a unit volume of concrete; improvement of the rheological properties of the plastic concrete; and increased strength and durability of the hardened concrete. However, prediction of the properties of fly ash concretes has proven difficult. This study is part of a larger program that seeks to examine the behavior of pozzolanic and cementitious mineral admixtures, their effects on the development of microstructure, and simulation modelling of microstructure and its development. This study examined the compositional and physical fly ash characteristics and their relationship to performance as measured by strength.

SEM images of the mortar microstructures shows that the broadening of the particle size distribution by the inclusion of the finer ash fraction results in a more uniform microstructure. Rims of hydration product are visible on the perimeter of the fly ash particles after 24 hours of hydration. As hydration proceeds, the paste microstructure becomes less porous, fly ash particles either exhibit a reaction rim, or appear inert with no reaction rim, or have partially dissolved leaving a semi-circular (in cross-section) void. Mortars sampled at 60 days exhibit a more dense, uniform microstructure but the pozzolanic reactions are still incomplete as remnants of un-reacted fly ash and calcium hydroxide are still present.

Pozzolanic reactivity of fly ash involves the dissolution of the glass, and is dependent on the composition of the glass and a high $\mathrm{pH}$ pore solution environment. X-ray diffraction data indicates a trend toward an increase in the glassy portion with ash size fractions below roughly $10 \mu \mathrm{m}$. Glass type as indicated by the position of the diffraction maximum does not exhibit appreciable change with particle size. Pozzolanic reactivity, as measured by strength gain, indicates a greater rate of reaction for the finer particles. As the reaction is not complete and the fly ash has not been completely consumed even at 60 days, it appears that the strength gains may be a result of the smaller particle size and resulting increase in specific surface area. Test specimens with equivalent specific surface area fly ash replacement as opposed to a fixed mass replacement may confirm this hypothesis.

\subsection{ACKNOWLEDGEMENTS}

The authors wish to thank Drs. Wecharatana and Liskowitcz of the New Jersey Institute of Technology for providing the fly ash samples. We also would like to acknowledge the assistance of reviewers Dale Bentz, Clarissia Ferraris, and Dick Livingston. 


\subsection{REEERENCES}

1. American Coal Ash Association, Inc., 1913 I Street N.W., 6th Eloor, Washington, D.C. 20006.

2. Berry, E.E., Hemmings, R.T., Langley, W.S., and Carette, G.G., "Beneficiated Fly Ash: Hydration, Microstructure, and Strength Development in Portland Cement Systems," in V.M. Malhotra, Ed., Proc. Third Internat. Conf. on The Use of Fly Ash, Silica Fume, Slag, and Natural Pozzolans in Concrete, ACI SP 114, pp. 241-273, 1989.

3. Giergiczny, Z. and Werynska, A. "Influence of Fineness of Fly Ashes on Their Hydraulic Activity," in V.M. Malhotra, Ed., Proc. Third Internat. Conf. on The Use of Fly Ash, Silica Fume, Slag, and Natural Pozzolans in Concrete, ACI SP 114, pp. 97-115, 1989.

4. Ukita, K., Ishii, M., Yamamoto, K., Azuma, K, and Kohno, K., "Properties of High Strength Concrete Using Classified Fly Ash," in V.M. Malhotra, Ed., Proc. Fourth Internat. Conf. on The Use of Fly Ash, Silica Fume, Slag, and Natural Pozzolans in Concrete, ACI SP 132, pp. 37-52, 1992.

5. Matsufujii, Y., Kohata, H., Tagaya, K., Teramoto, K., Okawa, Y., and Okazawa, S., "Study on Properties of Concrete with Ultra Fine Particles Produced from Fly Ash," in V.M. Malhotra, Ed., Proc. Fourth Internat. Conf. on The Use of Fly Ash, Silica Fume, Slag, and Natural Pozzolans in Concrete, ACI SP 132, pp. 351-365, 1992.

6. Jaturapitakkul, C.,"Utilization of Fly Ash in Concrete", Ph.D. Dissertation, New Jersey Institute of Technology, May, 1993.

7. Pietersen, H.S., "Reactivity of Fly Ash and Slag in Cement", Thesis, Delft University of Technology, Delft, The Netherlands, 1993.

8. Taylor, H.E.W., Cement Chemistry, Academic Press, San Diego, $\mathrm{CA}, 475 \mathrm{pp}, 1990$.

9. Bijen, J. and H. Pietersen, "Mineral Admixtures: Reactions, Micro-Structure and Macro-Properties," in M.W. Grutzek and S.L. Sarkar, Eds., Advances in Cement and Concrete, Proc. Eng. Eound.Conf., July, 24-29, 1994.

10. Kokubu, M., "Fly Ash and Fly Ash Cement," Proc. of the Fifth Internat. Symp. on the Chemistry of Cement, Tokyo, pp. 75 113, 1968.

11. Helmuth, R., Fly Ash in Cement and Concrete, Portland Cement Association, 1987, 203 pp. 
12. Standard Test Methods for Sampling and Testing Fly Ash or Natural Pozzolans for Use as a Mineral Admixture in Portland-Cement Concrete, American Society for Testing and Materials C 311-90, Vol. 4.02.

13. Standard Specification for Fly Ash and Raw or Calcined Natural Pozzolan for Use as a Mineral Admixture in Portland Cement Concrete, American Society for Testing and Materials C 618-91, Vol. 4.02.

14. Liskowitz, J.W., R.B. Trattner, J.M. Crow, M.S. Sheih, J.A. King, J. Kohut, and M. Zwillenberg, "Sorbent and Leachate Characteristics of Fly Ash," in Fossil Fuels Utilization: Environmental Concerns, R. Markuszewski and B.D. Blaustein, Eds., ACS Symposium Series No. 319, pp. 332-343, 1986.

15. Powder Diffraction File PDF-2 Database Sets 1-43, International Centex for Diffraction Data, Newton Square, $\mathrm{PA}, 1993$.

16. Klug, H.P. and L.E. Alexander, X-Ray Diffraction Procedures, John Wiley and Sons, New York, $966 \mathrm{pp} ., 1974$.

17. McCarthy, G.J., L.P. Keller, P.J. Shields, M.P. Elless, and K.C. Galbreath, "Mineralogical Characterization of a Lignite Gasification Ash from a Low-BTU Fixed-Bed Gasifier I. X-Ray Phase Analysis," Cement and Concrete Research, Vol. 14, pp. 479-484, 1984.

18. MCCarthy, G.J. and A. Thedchanamoorthy, "Semi-Quantitative $X$-Ray Diffraction Analysis of Fly Ash by the Reference Intensity Ratio Method," in Fly Ash and Coal Conversion By Products: Characterization, Utilization, and Disposal V, Mat. Res. Soc. Symp. Proc. Vol. 136, Materials Research Society, Pittsburgh, pp. 67-76, 1989.

19. Thedchanamoorthy, A. and G.J. McCarthy, "Semi-Quantitative XRD Analysis of Fly Ash Using Rutile as an Internal Standard," in Advances in X-Ray Analysis No. 32, Plenum Press, pp. 569-596, 1989 .

20. Snyder, R.L. and D.L. Bish, "Quantitative Analysis," in Modern Powder Diffraction, Reviews in Mineralogy, Vol. 20, D.L. Bish and J.E. Post, Eds., pp. 101-144, 1989.

21. Diamond, S., "On the Glass Present in Low-Calcium and in High-Calcium Flyashes," Cement and Concrete Research, Vol. 13, pp. 459-464, 1983 . 